\title{
IMPLEMENTATION SERVICES INFORMATION \\ TO OVERCOME THE FAILURE OF LEARNING
}

\author{
Sukatno \\ Universitas Muhammadiyah Tapanuli Selatan \\ Email: sukatno@um-tapsel.ac.id
}

abstrak

This study is based on problems that Many students who can not achieve the learning outcomes as expected by the educators in this case a failure in learning. The research goal is to describe the failure of student learning before and after the given service information, and determine the effectiveness of the implementation of information services in addressing the failure to learn. The method used in this research is True experimental design with pretest form-Posttest Control Group Design. With a sample of experimental class is class XI-TITL one of 25 students and the control class is class XI-TITL2 many as 22 students so as the total sample of 47 students. Data were analyzed using the Wilcoxon rank test signesd and Kolmogorov Smirnov 2 with the help SPPSS version 20.00. The results obtained in the experimental group of researchers pretest posttest 94.3 and 99.6 and the control group pretest posttest 87.3 and 93.7. Test the hypothesis produce the experimental group $\mathrm{Z}$ on pretest-posttest with values $-3,727 \mathrm{~b}$ and signed pretest-posttest worth 0.00 , whereas in the control group pretest-posttest $Z$ on the value $-3,232 b$ and signed pretest-posttest berniai 0.01. At posttest and posttest control experiments signed (2-tailed) 849 experimental group and the control group 940, while the average veriabel the experimental group 93.727399 .6800 in the control group. The conclusion is that the researchers obtained the experimental group was higher than the control group.

Keywords: Information Services, Overcoming Failure Study

\section{PENDAHULUAN}

Kegagalan adalah sebuah keadaan disaat kita tidak bisa mendapatkan sesuatu sesuai dengan keinginannya, Achi TM. (2011: 9) dan William A. Ward berkata, "Kegagalan adalah guru kita, bukan penghambat kita, kegagalan hanyalah keberhasilan yang tertunda, bukan kekalahan, sifatnya hanyalah sementara, tidak selamanya".

Jika anda tanamkan sikap seperti itu, Anda akan lebih leluasa menentukan langkah langkah yang harus diambil untuk mengatasi kegagalan. Anggaplah kegagalan adalah sarana untuk belajar.

edangkan Menurut Slameto. (2010:2) "Belajar adalah suatu proses usaha yang dilakukan seseorang untuk memperoleh suatu perubahan tingkah laku yang baru secara keseluruhan, sebagai hasil pengalamannya sendiri dalam interaksi dengan lingkungannya".
Sejalan dengan itu Menurut Irwanto (2002:105) "Belajar adalah sebagai suatu proses perubahan dari dalam diri individu dari belum tahu menjadi sudah tahu yang terjadi dalam waktu tertentu".

Sri A Dkk. ( 2008:2.5) menyatakan bahwa belajar merupakan suatu usaha yang dilakukan individu untuk memperoleh perubahan tingkah laku baru, secara keseluruhan sebagai pengalaman individu sendiri dalam berinteraksi dengan lingkungannya.

Berdasarkan latar belakang di atas, serta fenomena yang terjadi di sekolah maka penulis mengidentifikasikan masalah sebagai berikut ;

a. Banyak siswa yang menunjukan tidak dapat mencapai hasil belajar sebagaimana yang diharapkan oleh para pendidiknya.

b. Adanya peserta didik yang tidak dapat mengikuti pelajaran dengan lancar.

c. Ada siswa yang memperoleh prestasi belajar yang rendah. 
d. Siswa kurang minat dalam pelajaran yaitu 25 orang, dan kontrol kelas XI-TITL ${ }^{2}$ yaitu yang telah berlangsung.

e. Siswa membuat keributan saat proses belajar mengajar berlangsung. 22 orang dan berjumlah 47 orang.

\section{Teknik Pengumpulan Data}

Pelaksanaan penelitian adalah

f. Guru yang terlalu sering memberikan mempersiapkan instrument, guna mengadakan catatan tanpa menjelaskannya.

g. Kondisi kelas yang tidak nyaman.

\section{METODOLOGI} instrument penelitian, alat pengumpulan data dalam penelitian ini adalah angket. Menurut Suharsimi A. (2006:151) angket atau kuesionar adalah sejumlah pertanyaan tertulis yang digunakan untuk memperoleh informasi dari

Metode yang digunakan oleh penulis dalam responden. Jadi menurut peneliti Angket adalah penelitian adalah metode eksperimen. S. pertanyaan tertulis untuk memperoleh informasi Margono. (2010:10) menyatakan, metode seseorang.

eksperimen adalah metode penelitian yang Skala yang digunakan dalam penelitian ini melakukan percobaan terhadap kelompok- adalah skala likert. Sugiyono (2012:136) Skala kelompok eksperimen, kepada tiap kelompok likert digunakan untuk mengukur sikap, pendapat eksperimen yang dikenakan perlakuan-perlakuan dan persepsi seseorang atau sekelompok orang tertentu dengan kondisi yang dapat dikontrol. tentang fenomena sosial. Dalam penelitian,

Desain penelitian yang dipergunakan dalam fenomena sosial ini telah ditetapkan secara penelitian ini adalah kelompok kontrol pretest- spesifik oleh peneliti, yang selanjutnya disebut posttest (Pretest-Posttest Control Group Design) sebagai variabel penelitian.

\section{Populasi}

Sugiyono. (2004:55) mengatakan bahwa : "Populasi adalah wilayah generalisasi yang terdiri atas objek / subjek yang mempunyai kualitas dan karakteristiknya yang ditetapkan oleh peneliti untuk dipelajari kemudian ditarik kesimpulan".

Sesuai dengan pendapat di atas, maka populasi ini adalah seluruh siswa kelas XI. Yang mana jumlah populasinya 281 orang.

\section{Sampel}

Suharsimi A. (2006:109) : "sampel adalah bagian atau wakil populasi yang diteliti".

Sesuai dengan pendapat Suharsimi A. (2009:195) bahwa, "jumlah sampel yang diambil adalah $10-15 \%, 20-25 \%$ atau lebih tergantung kepada kemampuan peneliti baik ditinjau dari segi waktu, tenaga dan dana".

Berdasarkan pendapat di atas maka sampel penelitian yang ditetapkan adalah dengan menggunakan teknik total sampling dimana sebagian anggota

populasi dijadikan sebagai sampling penelitian ya itu Eksperimen kelas XI-TITL ${ }^{1}$
Dengan skala likert, maka variabel yang akan di ukur dijabarkan menjadi indikator variabel. kemudian indikator tersebut dijadikan sebagai titik tolak untuk menyusun item-item instrument yang dapat berupa pernyataan atau pertanyaan.

\section{Teknik Analisis Data}

Menurut Suharsimi A. (2010:327) analisis statistik inferensi adalah untuk menguji hipotesis yang diajukan apakah diterima atau ditolak.

Dalam penelitian ini, setelah data dari nilai tes awal (pre-test) dari kelas eksperimen dan kontrol telah terkumpul. Proses pengelolaan data menggunakan bantuan SPSS.

\section{HASIL}

Hasil pelaksanaan penelitian eksperimen yang dilakukan oleh peneliti dengan langkahlangkah sebagai berikut:

1. Diberikan pretest dengan melihat komunikasi interpersonal yang dimiliki siswa.

2. Peneliti memberikan treatment lima kali.

3. Setelah diberikan treatment selanjutnya diberikan posttest. 
Sedangkan penelitian kontrol yang dilakukan oleh kordinator BK dengan langkahlangkah sebagai berikut:

1. Diberikan pretest dengan melihat interpersonal yang dimiliki siswa.

2. Dilakukan layanan konvensional berupa layanan informasi.

3. Kordinator BK memberikan posttest.

Tabel. 1

Dilihat dari tabel di atas nilai perbandingan antara pretest-posttest kontrol dan prestest-posttest eksperiemen. Yang terjadi adalah nilai dari pretest-posttest eksperimen lebih tinggi dibandingkan prestest-posttest kontrol.

\section{PEMBAHASAN}

Berdasarkan hasil penelitian yang telah

Perbandingan hasil keseluruhan penelitian perindikator dijelaskan di atas sesuai dengan teori bahwa faktor-faktor tingkah laku menyimpang yang di ungkapkan oleh M. Dulyono (2012:55). Sesuai

\begin{tabular}{|c|c|c|c|c|c|c|}
\hline \multirow[b]{2}{*}{ No } & & \multirow[b]{2}{*}{ Indikator } & \multicolumn{2}{|c|}{ Eksperimen } & \multicolumn{2}{|c|}{ Kontrol dengan hasil penelitian yang didapat peneliti } \\
\hline & & & $\begin{array}{l}\text { Pre } \\
\text { test }\end{array}$ & $\begin{array}{c}\text { Post } \\
\text { test }\end{array}$ & $\begin{array}{l}\text { Pre } \\
\text { test }\end{array}$ & 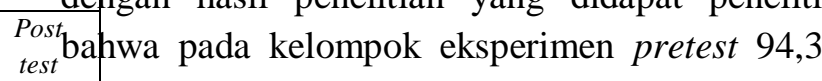 \\
\hline 1 & 1. & Kesehatan & 308 & 340 & 263 & 263setelah diberikan layanan informasi postte \\
\hline \multirow[t]{2}{*}{2} & 2. & $\begin{array}{l}\text { Intelegensi } \\
\text { dan bakat }\end{array}$ & 280 & 288 & 235 & $\begin{array}{c}\text { 248menjadi } 99,6 \text { sedangakn pada kelompok kont } \\
\text { pretest } 87,3 \text { dan setelah diberikan lavan }\end{array}$ \\
\hline & 3. & $\begin{array}{l}\text { Minat dan } \\
\text { motivasi } \\
\end{array}$ & 282 & 299 & 210 & informasi maka posttest menjadi 93,7 . Pad \\
\hline 3 & 4. & Cara belajar & 301 & 310 & 216 & ${ }_{253}$ pretest dan posttest eksperimen $-3,727^{\mathrm{b}}$ \\
\hline \multirow{2}{*}{4} & 5. & Keluarga & 409 & 437 & 318 & ${ }_{356}{ }^{\text {signed }}$ pretest-posttest bernilai 0,00 , sedangk \\
\hline & 6. & Sekolah & 323 & 337 & 283 & ${ }_{300} \mathrm{pada}$ kelompok kontrol $\mathrm{Z}$ pada pretest-post \\
\hline \multirow[b]{2}{*}{5} & 7. & Masyarakat & 197 & 214 & 158 & 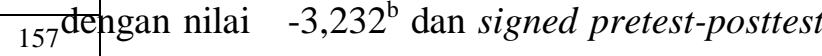 \\
\hline & 8. & $\begin{array}{l}\text { Lingkungan } \\
\text { sekolah }\end{array}$ & 259 & 267 & 238 & $\begin{array}{l}\text { berniai } 0,01 \text {. Pada posttest eksperimen } \\
250 \text { posttest kontrol signed (2-tailed) kelon }\end{array}$ \\
\hline
\end{tabular}
eksperimen 849 dan kelompok kontrol 940.

Data di atas diambil dari hasil tabulasi Terlihat bahwa pada kelompok eksperimen lebih per indikator dari pretest-posttest kontrol dan besar peningkatannya dibandingkan kelompok prestest-posttest eksperimen dan dengan adanya kontrol. Dapat disimpulkan bahwa layanan tabel perbandingan di atas dapat dilihat terjadinya informasi sangat efektif mengatasi kegagalan peningkatan sebelum dan sesudah diberikannya belajar siswa kalas XI TITL 1 dan TITL 2 di perlakuan.

Dari tabel di atas jika di lihat dari hasil

perbandingan interval yaitu sebagai berikut :

SMK Negeri 2 Padangsidimpuan.

\section{KESIMPULAN}

Tabel 2.

Kriteria Penilaian Kegagalan belajar

Layanan Informasi DI SMK Negeri 2 Padangsidimpuan

\begin{tabular}{|c|c|c|c|c|c|c|}
\hline \multirow[b]{2}{*}{ No } & \multirow{2}{*}{$\begin{array}{l}\text { Nilai } \\
\text { Interval }\end{array}$} & \multicolumn{2}{|c|}{ Eksperimen } & \multicolumn{2}{|c|}{ Kontrol } & \multirow[b]{2}{*}{ Kategori } \\
\hline & & $\begin{array}{l}\text { Pre } \\
\text { test }\end{array}$ & $\begin{array}{r}\text { Post } \\
\text { test }\end{array}$ & $\begin{array}{l}\text { Pre } \\
\text { test }\end{array}$ & $\begin{array}{c}\text { Post } \\
\text { test }\end{array}$ & \\
\hline 1 & $90-100$ & 94,3 & 99,6 & & 93,7 & Sangat baik \\
\hline 2 & $88-89$ & & & 87,3 & & Baik \\
\hline 3 & $70-79$ & & & & & Cukup \\
\hline 4 & $60-69$ & & & & & Kurang \\
\hline 5 & $0-59$ & & & & & Gagal \\
\hline
\end{tabular}

Berdasarkan hasil penelitian dapat disimpulkan sebagai berikut:

a. Pada kelompok eksperimen hasil posttest 99,6

b. Pada kelompok kontrol hasil posttest 93,7

c. Pada $\mathrm{Z}$ pretest dan posttest eksperimen -

$4,206^{\mathrm{b}}$ dan signed pretest-posttest bernilai 0,00 .

d. pada kelompok kontrol $\mathrm{Z}$ pada pretestposttest dengan nilai $-3,472^{\mathrm{b}}$ dan signed pretest-posttest berniai 0,01 . 
e. Pada posttest eksperimen dan posttest kontrol signed (2-tailed) kelompok eksperimen 422 dan kelompok kontrol 769 .

Jadi, hasil penelitian pada kelompok eksperimen lebih tinggi dari pada hasil penelitian pada kelompok kontrol.

\section{DAFTAR PUSTAKA}

M.Dulyono., 2012. Psikologi Pendidikan. Jakarta: Rineka Cipta

Achi TM.,2011. Aku Bangga Menjadi Gagal. Jakarta. Grasindo

Irwanto., 2002. Psikologi Umum (Buku Panduan Mahasiswa). Jakarta: Prenhallindo. Universitas Suharsimi,A., 2006. Prosedur Penelitian. Jakarta. Rineka Cipta.

Suharsimi, A., 2009. Prosedur Penelitian. Jakarta. Rineka Cipta.

Suharsimi,A., 2010. Menejemen Penelitian. Jakarta. Rineka Cipta.

S. Margono., 2010. Metodologi Penelitian Pendidikan. Jakarta. Rineka Cipta

Slameto., 2010. Belajar dan Faktor-Faktor yang Mempengaruhinya. Jakarta: Rineka Cipta

Sri A W, Dkk., 2008. Statgi Pemelajaran. Jakarta. Universitas Terbuka

Sugiyono., 2004. Statistika Untuk Penelitian. Bandung: Alfabeta.

Sugiyono., 2012. Metode Penelitian Kombinasi (Mixed Methods). Bandung. Alfabeta 